Jurnal Gizi Klinik Indonesia

Vol. 17 No. 3, Januari 2021 (125-132)

ISSN 1693-900X (Print), ISSN 2502-4140 (Online)

Tersedia online di https://jurnal.ugm.ac.id/jgki

DOI: https://doi.org/10.22146/ijcn.62154

\title{
Status gizi dan gambaran klinis penyakit pada pasien HIV anak awal terdiagnosis
}

\author{
Nutritional status and clinical disease of HIV children patients when diagnosed for the first time

\section{Ratni Indrawanti ${ }^{1}$, Egi Arguni ${ }^{2}$, Ida Safitri Laksanawati ${ }^{2}$, Dwiyanti Puspitasari ${ }^{1}$, Dominicus Husada ${ }^{1}$}

${ }^{1}$ Divisi Infeksi dan Penyakit Tropis, Departemen/SMF Ilmu Kesehatan Anak, Fakultas Kedokteran, Universitas Airlangga/ Rumah Sakit Umum Daerah Dr. Soetomo, Surabaya

${ }^{2}$ Divisi Infeksi dan Penyakit Tropis, Departemen Ilmu Kesehatan Anak, Fakultas Kedokteran, Kesehatan Masyarakat, dan Keperawatan, Universitas Gadjah Mada/ KSM Kesehatan Anak, Rumah Sakit Umum Pusat Dr. Sardjito, Yogyakarta

\begin{abstract}
Background: Human immunodeficiency virus (HIV) infection in children can cause nutritional problems. Currently, HIV-infected children are still diagnosed when the disease stage is advanced. Nutritional status is a marker of advanced stage conditions in HIV infection. Objective: To determine the clinical findings of disease and nutritional status of HIV children patients when diagnosed for the first time. Methods: We conducted a cross-sectional descriptive study. The data were taken from the medical record documents of child patients aged 0-18 years with the ICD 10 code B20, who was treated at the Dr. Sardjito Yogyakarta Hospital from 1 January 2004-31 December 2019. Results: There were 191 children diagnosed with HIV, 56\% of them were boys. The median age was 34 months (IQR 25: 13 months, IQR 75: 69 months), and 95.5\% among those were infected perinatally. There were 77 (40,3\%) children who suffered from severe malnutrition and $55(28.8 \%)$ children were moderate acute malnutrition. At the age of 0-60 months among them, there were 49 children (36.3\%) suffered from severely underweight, 35 children (25.9\%) underweight, 53 (39.3\%) severely stunted, $38(28.1 \%)$ stunted, 28 severely wasted (20.7\%), and wasted as many as $24(17.8 \%)$. At the age of 5-18 years old, there were $19(33.9 \%)$ and $5(8.9 \%)$ children who suffered from severely wasted and wasted respectively. World Health Organization (WHO) stages 3 and 4 were experienced by 62 (32.5\%) and 68 (35.6\%) children. As many as $41.3 \%$ of children had enlarged lymph nodes, thrush (40.8\%), pneumonia (40.8\%), and persistent or chronic diarrhea (21.5\%). Conclusions: The nutritional status of HIV-infected children at baseline was dominated by underweight and stunted. The most clinical findings of the disease when the child was diagnosed with HIV infection were lymphadenopathy, oral thrush, pneumonia, and persistent or chronic diarrhea.
\end{abstract}

KEYWORDS: children; clinical disease; HIV; nutritional status

\begin{abstract}
ABSTRAK
Latar belakang: Infeksi HIV pada anak dapat menyebabkan gangguan gizi. Saat ini, masih ditemukan anak terinfeksi HIV yang terdiagnosis ketika stadium penyakit sudah lanjut. Status gizi merupakan salah satu penanda kondisi stadium lanjut pada infeksi HIV. Tujuan: Penelitian ini bertujuan untuk mengetahui gambaran klinis penyakit dan status gizi pasien anak HIV saat terdiagnosis pertama kali. Metode: Penelitian potong lintang, deskriptif. Data diambil dari dokumen rekam medis pasien anak usia 0-18 tahun dengan kode ICD 10 B20, yang berobat di RSUP Dr. Sardjito Yogyakarta sejak 1 Januari 2004-31 Desember 2019. Hasil: Sejumlah 191 anak yang terdiagnosis HIV positif. Sebanyak 56\% berjenis kelamin laki-laki dengan median usia 35 bulan (IQR 25: 13 bulan dan IQR 75: 69 bulan) serta 95,5\% terinfeksi saat perinatal. Anak mengalami gizi buruk sebanyak 40,3\% dan gizi kurang sebanyak $28,8 \%$. Pada kelompok usia $0-60$ bulan terdapat 49 anak (36,3\%) menderita severely underweight; 35 anak $(25,9 \%)$ underweight; 53 anak (39,3\%) severely stunted; 38 anak $(28,1 \%)$ stunted; 28 anak (20,7\%) severely wasted; dan 24 anak (18,7\%) menderita wasted. Pada kelompok usia 5-18 tahun terdapat 19 anak (33,9\%) dan 5 anak $(8,9 \%)$ berturut-turut menderita severely wasted dan wasted. Stadium klinis HIV menurut WHO ditemukan 3 dan 4 dialami oleh 62 anak $(32,5 \%)$ dan 68 anak (35,6\%). Sebanyak $41,3 \%$ anak mengalami pembesaran kelenjar getah bening; kandidiasis (40,8\%); pneumonia (40,8\%); dan diare persisten/kronis
\end{abstract}

Korespondensi: Dominicus Husada, Departemen Ilmu Kesehatan Anak, Fakultas Kedokteran, Universitas Airlangga, Jalan Mayjen. Prof. Dr. Moestopo No. 6-8, Surabaya, Indonesia,e-mail: dominicushusada@yahoo.com

Cara sitasi: Indrawanti R, Arguni E, Laksanawati IS, Puspitasari D, Husada D. Status gizi dan gambaran klinis penyakit pada pasien HIV anak awal terdiagnosis. Jurnal Gizi Klinik Indonesia. 2021;17(3):125-132. doi: 10.22146/ijcn.62154 
(21,5\%). Simpulan: Status gizi pasien anak HIV saat awal terdiagnosis didominasi oleh underweight dan stunted. Gambaran klinis penyakit terbanyak saat anak awal terdiagnosis adalah limfadenopati, oral trush, pneumonia, dan diare persisten atau kronis.

KATA KUNCI: anak; klinis penyakit; HIV; status gizi

\section{PENDAHULUAN}

Sampai saat ini, kasus human immunodeficiency virus (HIV) pada anak masih merupakan masalah di Indonesia. Meskipun secara global, sejak tahun 2000 hingga saat ini, infeksi baru dan kematian akibat HIV/ acquired immunodeficiency syndrome (AIDS) menjukkan tren yang menurun, tetapi laporan kasus baru HIV anak di Indonesia tetap meningkat(1). Human immunodeficiency virus menyerang sistem kekebalan tubuh. Penurunan imunitas yang berat menyebabkan anak HIV positif sangat rentan terhadap infeksi lain. Anak terinfeksi HIV biasanya tidak meninggal secara langsung oleh karena penyakit infeksi HIV itu sendiri, melainkan lebih sering disebabkan oleh infeksi oportunistik yang menyertainya.

Persentase klinis infeksi HIV bervariasi sesuai dengan tingkat imunosupresi yang terjadi, mulai dari infeksi asimtomatik hingga AIDS yang ditandai oleh imunosupresi parah dan infeksi oportunistik parah berulang. Pola penyakit penyerta yang dominan pada anak HIV positif meliputi infeksi saluran pernapasan, malnutrisi, dan diare (2). Kondisi ini juga lazim ditemukan anak tanpa infeksi HIV. Hal ini dapat menyebabkan tingkat kecurigaan klinisi terhadap infeksi HIV rendah sehingga berakibat diagnosis infeksi HIV terlambat ditegakkan. Penelitian di Ethiopia melaporkan bahwa 71,5\% pasien HIV anak terdiagnosis saat penyakit sudah lanjut (stadium World Health Organization/WHO 3 dan 4), serta 51,6\% pasien tersebut menderita gizi buruk atau gizi kurang (3). Kondisi status gizi telah dilaporkan berhubungan dengan progresivitas infeksi HIV (4). Pengenalan klinis penyakit dan kewaspadaan adanya status gizi buruk dan kurang pada anak terinfeksi HIV sangat penting supaya diagnosis dapat segera ditegakkan dan anak dapat tertangani dengan baik. Keterlambatan penegakan diagnosis pada anak terinfeksi HIV menyebabkan pemberian terapi antiretroviral (ARV) ikut terlambat. Anak terinfeksi HIV yang dapat tegak terdiagnosis serta diberikan terapi ARV dini memiliki kondisi klinis dan imunologis yang lebih baik daripada jika terapi ARV diberikan saat kondisi penyakit sudah lanjut (5). Di Indonesia, penelitian tentang kondisi awal anak terdiagnosis HIV masih jarang. Penelitian ini bertujuan untuk mengetahui kondisi klinis penyakit dan status gizi awal pasien HIV anak saat terdiagnosis.

\section{BAHAN DAN METODE}

\section{Desain dan subjek}

Penelitian menggunakan rancang bangun potong lintang yang dilaksanakan di Rumah Sakit Umum Pusat (RSUP) Dr. Sardjito Yogyakarta pada bulan AgustusSeptember 2020. Sampel menggunakan total sampling dari seluruh pasien HIV anak yang berobat di RSUP Dr. Sardjito sejak 1 Januari 2004 sampai dengan 31 Desember 2019. Kiteria inklusi adalah anak usia 0-18 tahun yang terdiagnosis infeksi HIV dengan kode ICD 10: B20. Kriteria eksklusi adalah data rekam medis tidak lengkap. Diagnosis infeksi HIV ditegakkan berdasarkan kriteria temuan klinis yang mengarah pada kondisi imunokompromais dan pemeriksaan laboratorium. Pemeriksaan virologi berupa PCR RNA (viral load) dilakukan pada anak usia kurang dari 18 bulan dan pemeriksaan antibodi dilakukan pada anak usia lebih dari 18 bulan.

\section{Pengumpulan dan pengukuran data}

Variabel yang diteliti adalah umur (bulan), jenis kelamin, status gizi, stadium klinis berdasarkan World Health Organization (WHO), dan gambaran klinis penyakit HIV yaitu limfadenopati umum, oral thrush (jamur di mulut), dan diare persisten atau diare kronis.

Status gizi. Variabel status gizi pasien ditegakkan berdasarkan pemeriksaan antropometri sesuai dengan standar antropometri anak berdasarkan WHO Child Growth Standars (6) untuk anak usia 0-5 tahun dan The WHO Reference 2006 (7) untuk anak 5-18 tahun. Status gizi pada penelitian ini dibedakan menjadi dua kelompok berdasarkan Permenkes No. 2 Tahun 2020, yaitu 
kelompok usia 0-60 bulan dan kelompok usia 5-18 tahun. Pada kelompok pasien usia 0-60 bulan, penentuan status gizi berdasarkan berat badan menurut umur $(\mathrm{BB} / \mathrm{U})$, panjang badan menurut umur $(\mathrm{PB} / \mathrm{U})$ atau tinggi badan menurut umur (TB/U), dan berat badan menurut panjang badan $(\mathrm{BB} / \mathrm{PB})$ atau berat badan menurut tinggi badan (BB/TB). Pada kelompok usia 5-18 tahun, penentuan status gizi berdasarkan indeks masa tubuh menurut umur (IMT/U).

Gambaran klinis penyakit HIV. Limfadenopati general (umum) adalah pembesaran kelenjar getah bening di beberapa tempat seperti di leher, belakang telinga, ketiak dan selangkangan, dapat tunggal atau lebih dari satu (8). Oral thrush (jamur di mulut) adalah lapisan keputihan mirip krem di lidah, pipi bagian dalam, dan kadang-kadang di langit-langit mulut, gusi, dan amandel, kadang terdapat kemerahan di tepinya yang disertai rasa nyeri saat makan dan menelan yang disebabkan oleh Candida sp (9). Diare adalah peningkatan jumlah (tiga kali atau lebih) atau perubahan konsistensi tinja (menjadi lunak atau cair) dalam waktu 24 jam. Diare persisten yaitu kejadian diare lebih dari dua minggu yang disebabkan oleh infeksi (10). Pneumonia adalah peradangan pada paru yang ditandai oleh batuk dan napas cepat sesuai usia, serta tarikan dinding dada (11).

\section{Analisis data}

Pengolahan data menggunakan SPSS versi 22 dan disajikan dalam bentuk frekuensi. Penelitian ini sudah mendapatkan kelaikan etika penelitian No Ref. Ni: KE/ FK/0897/EC/2020.

\section{HASIL}

Sejumlah 191 anak yang terdiagnosis sebagai infeksi HIV, terdiri dari 107 anak laki-laki (56\%) dan 86 anak perempuan (44\%). Median umur pertama kali anak terdiagnosis adalah 34 bulan (IQR 25: 13 bulan dan IQR 75: 69 bulan). Berdasarkan kelompok usia, pasien usia 0-60 bulan ditemukan sebanyak 135 anak (70,7\%) dan 56 anak berusia lebih dari 5 tahun (29,3\%). Status gizi pasien usia 0-60 bulan menurut BB/U, didapatkan sebanyak 36,3\% pasien menderita severely underweight dan $25,9 \%$ pasien underweight. Berdasarkan $\mathrm{PB} / \mathrm{U}$ atau TB/U, severely stunted dialami oleh 39,3\% pasien sedangkan stunted oleh $28,1 \%$ pasien. Menurut BB/PB atau BB/TB, didapatkan 20,7\% pasien mengalami severely wasted dan $17,8 \%$ mengalami wasted. Menurut IMT/U pada kelompok pasien usia 5-18 tahun, didapatkan severely wasted dan wasted masingmasing sebesar 33,9\% dan 8,9\%. Sebagian besar anak memiliki stadium klinis WHO 3 dan 4 masing-masing sebesar 32,5\% dan 35,6\% (Tabel 1).

Tabel 1. Karakteristik pasien HIV anak

\begin{tabular}{|c|c|c|}
\hline Karakteristik & n & $\%$ \\
\hline \multicolumn{3}{|l|}{ Jenis kelamin } \\
\hline Laki-laki & 107 & 56,0 \\
\hline Perempuan & 84 & 44,0 \\
\hline \multicolumn{3}{|c|}{ Usia pertama kali terdiagnosi infeksi HIV } \\
\hline$<1$ tahun & 45 & 23,6 \\
\hline $1-5$ tahun & 90 & 47,1 \\
\hline$>5$ tahun & 56 & 29,3 \\
\hline \multicolumn{3}{|l|}{ Stadium klinis WHO } \\
\hline 1 & 11 & 5,8 \\
\hline 2 & 50 & 26,2 \\
\hline 3 & 62 & 32,4 \\
\hline 4 & 68 & 35,6 \\
\hline \multicolumn{3}{|l|}{ Alamat } \\
\hline Yogyakarta & 126 & 66,0 \\
\hline Luar Yogyakarta & 65 & 34,0 \\
\hline \multicolumn{3}{|l|}{ Status gizi } \\
\hline Buruk & 77 & 40,3 \\
\hline Kurang & 55 & 28,8 \\
\hline Baik & 58 & 30,4 \\
\hline Lebih & 1 & 0,5 \\
\hline \multicolumn{3}{|l|}{ Pasien usia $0-60$ bulan } \\
\hline \multicolumn{3}{|l|}{ Status gizi menurut $\mathrm{BB} / \mathrm{U}$} \\
\hline Severely underweight & 49 & 36,3 \\
\hline Underweight & 35 & 25,9 \\
\hline Normal & 47 & 34,8 \\
\hline Risiko gizi lebih & 4 & 3,0 \\
\hline \multicolumn{3}{|c|}{ Status gizi menurut $\mathrm{PB} / \mathrm{U}$ atau $\mathrm{TB} / \mathrm{U}$} \\
\hline Severely stunted & 53 & 39,3 \\
\hline Stunted & 38 & 28,1 \\
\hline Normal & 42 & 31,1 \\
\hline Tinggi & 2 & 1,5 \\
\hline \multicolumn{3}{|c|}{ Status gizi menurut $\mathrm{BB} / \mathrm{PB}$ atau $\mathrm{BB} / \mathrm{TB}$} \\
\hline Severely wasted & 28 & 20,7 \\
\hline Wasted & 24 & 17,8 \\
\hline Normal & 81 & 60,0 \\
\hline Risiko overweight & 2 & 1,5 \\
\hline \multicolumn{3}{|l|}{ Pasien usia $>5-18$ tahun } \\
\hline \multicolumn{3}{|l|}{ Status gizi menurut IMT/U } \\
\hline Severely wasted & 19 & 33,9 \\
\hline Wasted & 5 & 8,9 \\
\hline Gizi baik (normal) & 31 & 55,4 \\
\hline Risiko overweight & 1 & 1,8 \\
\hline
\end{tabular}


Tabel 2. Gambaran klinis yang sering dijumpai

\begin{tabular}{lcc}
\hline Gambaran klinis & n & \% \\
\hline Pembesaran kelenjar getah bening & 79 & 41,3 \\
Jamur di mulut & 78 & 40,8 \\
Pneumonia & 50 & 26,2 \\
Diare persisten/kronis & 41 & 21,5 \\
\hline
\end{tabular}

Tabel 2 menunjukkan temuan klinis yang sering dijumpai pada anak terinfeksi HIV. Temuan paling sering adalah limfadenopati umum sebesar 41,3\%. Oral thrush diderita oleh 78 (40,8\&) anak, pneumonia oleh $50(26,2 \%)$, dan diare persisten atau kronis dialami oleh $41(21,5 \%)$.

\section{BAHASAN}

Berdasarkan data anamnesis, seluruh pasien ini memiliki salah satu atau kedua orang tua positif HIV sehingga kemungkinan mereka mendapatkan HIV dari ibunya. World Health Organization menyebutkan 95\% anak tertular dari ibunya saat perinatal (12). Penelitian ini mendapatkan hasil bahwa anak laki-laki lebih banyak dari pada perempuan. Hal ini mendukung penelitian di Benin Afrika barat yang juga mendapatkan persentase anak lakilaki terinfeksi HIV lebih banyak (13). Selama di dalam kandungan dan saat persalinan, bayi perempuan lebih 1,5-2 kali rentan tertular HIV dari ibu, tetapi selanjutnya bayi laki-laki lebih banyak mendapat transmisi HIV melalui air susu ibu (ASI) (14). Median usia pertama kali anak didiagnosis HIV pada penelitian ini adalah 34 bulan. Hasil ini mirip dengan temuan penelitian di Zambia (15). Penelitian lain di Afrika Selatan dan Thailand mendapatkan usia terdiagnosis yang lebih tinggi $(16,17)$. Sebagian besar anak datang dalam kondisi penyakit lanjut (stadium WHO 3 dan 4) dan dalam kondisi status gizi buruk atau kurang.

Usia terdiagnosis HIV positif pada subjek penelitian ini sebagian besar $(48,2 \%)$ adalah usia 1-5 tahun. Berdasarkan progres penyakit, sebagian besar kondisi penyakit pada stadium WHO 3 dan 4. Apabila dihubungkan dengan usia 1-5 tahun dan kondisi stadium penyakit berat, maka sangat mungkin anak-anak ini merupakan golongan rapid progressor. Menurut progres penyakit, anak terinfeksi HIV dibedakan menjadi rapid progressor, intermediate progressor, dan slow progressor (18). Transmisi HIV pada rapid progressor diduga terjadi selama intrauteri. Rapid progressor mengalami perkembangan penyakit sangat cepat, gejala dan tanda muncul pada usia 1-2 atau 3 bulan pertama kehidupan, median survival 6-9 bulan, virus dapat terdeteksi pada 48 jam pertama, dan bila tidak ditangani dapat meninggal pada usia 1-2 tahun.

Mayoritas pasien (62,2\%) mengalami severely underweight dan underweight berdasarkan indikator $\mathrm{BB} / \mathrm{U}$ dan $67,4 \%$ pasien mengalami severely stunted dan stunted berdasarkan indikator $\mathrm{PB} / \mathrm{U}$ sedangkan menurut indikator $\mathrm{BB} / \mathrm{PB}$ atau $\mathrm{BB} / \mathrm{TB}$ ditemukan pasien mengalami severely wasted sebesar $20,7 \%$ dan wasted sebesar $17,8 \%$. Penelitian ini juga mendapatkan hasil bahwa status gizi anak usia $>5$ tahun-18 tahun menurut IMT/U didapatkan severely wasted sebesar 33,9\% dan wasted sebesar 8,9\%. Sebagian pasien HIV anak usia 0-60 bulan yang datang ke rumah sakit dalam kondisi severely stunted dan stunted. Hal ini menunjukkan bahwa sebagian besar pasien saat terdiagnosis menderita kekurangan gizi yang kronis.

Underweight didefinisikan sebagai berat badan rendah berdasarkan usia (19). Underweight mencerminkan kondisi saat ini akibat asupan makanan yang tidak memadai, episode kurang gizi di masa lalu, atau kondisi kesehatan yang buruk (20). Stunted didefinisikan sebagai tinggi badan rendah berdasarkan usia yang terjadi akibat kekurangan gizi kronis atau berulang. Stunted merefleksikan adanya gangguan yang dialami anak akibat gizi buruk, infeksi berulang, dan stimulasi psikososial yang tidak memadai (19). Stunted biasanya berhubungan dengan kemiskinan, kesehatan dan gizi ibu yang buruk, penyakit yang sering diderita dan atau pemberian makan atau perawatan yang tidak tepat di awal kehidupan. Stunted harus segera ditangani agar anak dapat mencapai potensi fisik dan kognitif mereka (20). Wasted didefinisikan sebagai berat badan rendah berdasarkan tinggi badan. Wasted menunjukkan penurunan berat badan baru-baru ini dan parah, meskipun juga bisa bertahan lama. Wasted terjadi akibat seseorang tidak mendapatkan makanan dengan kualitas dan kuantitas yang memadai dan atau sering atau lama menderita penyakit. Wasted pada anak dikaitkan dengan 
risiko kematian yang lebih tinggi jika tidak ditangani dengan baik (20).

Salah satu faktor yang menyebabkan masalah gizi pada anak yang terinfeksi HIV adalah nafsu makan yang berkurang, yang mungkin disebabkan oleh kesulitan saat menelan makanan akibat infeksi jamur yang luas termasuk kandiasis oral, kandidiasis esofagus, dan esofagitis CMV (21). Faktor lain diduga karena penyerapan nutrisi yang buruk akibat diare (22). Saluran pencernaan adalah organ limfoid terbesar di tubuh dan secara langsung dipengaruhi oleh infeksi HIV. Human immunodeficiency virus menyebabkan kerusakan pada vili sel usus hingga vili menjadi rata dan menyebabkan penurunan penyerapan D-xilosa (23). Hal ini berakibat terjadinya malabsorpsi karbohidrat dan lemak sehingga memengaruhi penyerapan vitamin larut lemak seperti vitamin A dan E, yang penting untuk berfungsinya sistem kekebalan tubuh (24,25). Asupan gizi dalam jumlah yang lebih besar dibutuhkan selama demam dan infeksi yang menyertai infeksi HIV, tetapi asupan gizi tidak dimanfaatkan dengan baik oleh tubuh yang berakibat terjadinya penurunan berat badan dan jaringan otot serta lemak, selanjutnya menyebabkan kerusakan pada sistem kekebalan.

Faktor penyebab lain kekurangan gizi pada pasien HIV adalah keterlambatan datangnya layanan medis (26). Hal ini sesuai dengan kondisi pasien pada penelitian ini yaitu sebagian besar anak datang ke rumah sakit sudah terdiagnosis dalam kondisi lanjut yaitu stadium klinis WHO 3 dan 4. Jika dibandingkan dengan anak non-HIV, pasien HIV anak memiliki kebutuhan kalori harian yang lebih tinggi dan membutuhkan mikronutrien yang lebih banyak. Stunted dan wasted mencerminkan kondisi kekurangan gizi yang kronis. Pada pasien HIV anak, stunted dan wasted tidak hanya mencerminkan interaksi proses biologis, tetapi juga mencakup serangkaian kegagalan dalam sistem kesehatan, rumah, dan komunitas. Kombinasi pendapatan yang berkurang karena kelemahan, tabungan dan aset yang berkurang, dan kematian orang dewasa HIV positif yang tinggi, menyebabkan kerawanan pangan di rumah tangga HIV. Kerawanan pangan meningkatkan risiko malnutrisi pada anak-anak dalam rumah tangga (4).

Penelitian di Lagos mendapatkan hasil bahwa prevalensi underweight, stunted dan wasted berturut- turut adalah sebesar $18,5 \% ; 17,15 \%$; dan $17,5 \%$, serta prevalensi ini tiga kali lebih tinggi dibandingkan dengan anak yang tidak menderita HIV (19). Prevalensi underweight, stunted dan wasted pada penelitian ini lebih tinggi dibandingkan dengan penelitian sebelumnya (19). Kemungkinan hal ini karena perbedaan kondisi pasien. Saat datang ke rumah sakit, sebagian besar pasien (68\%) penelitian ini sudah dalam stadium klinis WHO 3 dan 4 yang status gizi buruk dan kurang digunakan sebagai kriteria. Sementara penelitian sebelumnya (19) tidak menyebutkan kondisi pasien saat diteliti.

Gambaran klinis berupa limfadenopati pada penelitian ini ditemukan pada 41,3\% anak. Limfadenopati pada anak dengan HIV positif mungkin disebabkan oleh berbagai kondisi non-neoplastik (non-infeksi dan infektif) dan neoplastik. Perubahan reaktif dan penyakit infeksi, kebanyakan etiologi mikobakteri, paling sering ditemui. Kondisi neoplastik yang umum termasuk limfoma nonHodgkin (limfoma Burkitt dan limfoma sel B besar yang menyebar) dan sarkoma Kaposi (9).

Lebih lanjut, oral trush (jamur di mulut) ditemukan pada 40,8\% anak. Candida albicans merupakan flora normal di mulut pada orang yang tidak imunokompromais. Pada penderita infeksi HIV dengan kondisi imunokompromis berat terjadi penurunan imunitas tubuh dengan konsekuensi Candida yang tadinya merupakan flora normal dapat menjadi infeksi yang kronis, berulang, dan sulit diobati. Pertumbuhan Candida pada mukosa mulut yang berlebihan menyebabkan deskuamasi sel epitel, penumpukan jamur, keratin, dan jaringan nekrotik yang bergabung membentuk pseudomembran, yang mungkin melekat erat pada mukosa. Temuan infeksi jamur pada pasien di penelitian ini mengindikasikan bahwa hampir separuhnya mengalami kondisi imunokompromais berat. Temuan jamur di mulut pada penelitian ini lebih tinggi daripada laporan di Rumah Sakit Adam Malik Medan yang melaporkan jamur di mulut ditemukan pada 33,9\% pasien (26). Lebih tingginya temuan jamur di mulut pada penderita HIV anak mengindikasikan kemungkinan petugas kesehatan masih kurang mengenali tanda ini sejak awal.

Pneumonia pada penelitian ini dialami oleh $26,2 \%$ pasien. Pneumonia merupakan penyakit pernapasan yang 
sering terjadi pada infeksi HIV di samping penyakit infeksi pernapasan lain seperti tuberculosis dan sinusitis. Paru adalah organ target utama untuk infeksi HIV karena pada paru penderita HIV didapatkan penurunan jumlah sel limfosit T, limfosit B, fibroblast paru, makrofag, sel natural killer, eosinofil, monosit, dan sel dendritik. Berkurangnya dalam hal kuantitatif dan fungsional yang progresif dari sel $\mathrm{T}$ limfosit CD4 dan subset imunologis lainnya berakibat pasien lebih rentan terhadap berbagai komplikasi infeksi dan non-infeksi (27). Limfosit di dalam darah dan di alveolar pada penderita HIV dan nonHIV yang mengalami Pneumocystis Pneumonia (PCP), menyimpulkan bahwa sel T CD4 alveolar yang lebih rendah adalah prediktif pada kejadian PCP (28). Pada penderita HIV, jumlah sel T CD4 alveolar berkorelasi kuat dengan sel T CD4 perifer yang menggambarkan adanya hubungan antara fungsi kekebalan paru-paru dan fungsi kekebalan sistemik pada HIV. Jika dibandingkan dengan orang non-HIV, penderita HIV memiliki fungsi sel T CD4 alveolar yang terganggu. Penderita HIV memiliki sel T CD4 untuk antigen spesifik yang lebih rendah sehingga respons terhadap influenza, Streptococcus pneumoniae, dan Mycobacterium tuberculosis (MTB) berkurang serta respons makrofag alveolar terhadap bakteri juga berkurang (29).

Kejadian diare persisten atau kronis pada penelitian ini ditemukan pada 21,5\% anak. Etiologi diare pada pasien yang terinfeksi HIV dapat dibagi menjadi dua kategori utama yaitu non-infeksi dan infeksi. Diare non-infeksi pada HIV dapat disebabkan oleh enteropati HIV, ARTassociated diarrhea, irritable bowel syndrome (IBS), dan small intestinal bacterial overgrowth (SIBO) (24). Diare akibat infeksi, dapat disebabkan oleh organisme bakteri, virus, jamur, dan parasit. Enteropati HIV adalah bentuk diare idiopatik yang diamati pada pasien dengan HIV tanpa adanya sumber infeksi dengan ciri histologis yang khas yaitu adanya peradangan pada mukosa usus, terjadi malabsorpsi vitamin B12 dan asam empedu, meningkatkan permeabilitas usus, penurunan berat badan, terdapat gambaran histologis berhubungan dengan infiltrat limfosit inflamasi, kerusakan pada epitel usus, termasuk vili atrofi dan tumpul serta hiperplasia kripta (23). Enteropati HIV dapat terjadi pada semua tahap infeksi HIV, dari HIV akut hingga AIDS lanjut. Human immunodeficiency virus diduga mampu menginfeksi epitel mukosa dan merusak barier mukosa usus halus yang berakibat pada penurunan resistensi transepitel dan diare. Mekanisme enteropati HIV diduga meliputi penurunan resistensi listrik transepitelial, penurunan penyerapan glukosa yang bergantung natrium, dan peningkatan permeabilitas antar sel di dalam sel yang terinfeksi HIV (22).

Penelitian lain di Rumah Sakit Adam Malik Medan melaporkan kejadian diare pada anak HIV sebesar 26,4\% (26), tetapi tidak dijelaskan lebih lanjut mengenai jenis diare akut, peristen, atau kronis. Temuan diare persisten pada penelitian ini hampir sama dengan temuan pada pasien HIV anak di Medan. Kejadian diare tidak telepas dari hygiene perorangan dan penyediaan air bersih, yang selanjutnya hal ini menjadi tantangan dalam menangani pasien HIV anak. Gangguan gizi yang menyertai infeksi HIV pada anak akan saling memperparah kedua kondisi tersebut. Selain itu, anak HIV positif yang mengalami severely wasted dilaporkan lebih banyak mengalami diare, pneumonia, infeksi kulit yang luas, dan sariawan oral yang persisten, yang berkontribusi pada peningkatan fatalitas kasus dan respons yang lebih buruk terhadap manajemen (30).

Berdasarkan uraian di atas, mengetahui status gizi anak yang disertai dengan gambaran klinis infeksi HIV seperti adanya limfadenopati umum, jamur di mulut yang luas dan berulang, anak menderita pneumonia berulang, dan diare persisten atau kronis, diharapkan dapat meningkatkan kewaspadaan akan adanya kondisi imunokompromais yang salah satunya disebabkan oleh infeksi HIV.

\section{SIMPULAN DAN SARAN}

Gambaran klinis penyakit terbanyak pada pasien HIV anak yang pertama kali terdiagnosis adalah limfadenopati, oral trush, pneumonia, dan diare persisten atau kronis, serta didominasi oleh status gizi buruk dan kurang.

\section{UCAPAN TERIMA KASIH}

Terimakasih kepada dr. Conroy yang telah membantu mengumpulkan data. 
Pernyataan konflik kepentingan

Tidak ada konflik kepentingan apapun pada penelitian ini.

\section{RUJUKAN}

1. Roser, Ritchie. HIV/AIDS [series online] 2020 [cited 2020 Maret 4]. Available from: URL: https://ourworldindata. org/hiv-aids

2. Ogunbosi BO, Oladokun RE, Brown BJ, Osinusi KI. Prevalence and clinical pattern of paediatric HIV infection at the University College Hospital, Ibadan, Nigeria: a prospective cross-sectional study. Ital J Pediatr. 2011;37:29. doi: 10.1186/1824-7288-37-29

3. Adem AK, Alem D, Girmatsion F. Factors affecting survival of HIV positive children taking antiretroviral therapy at Adama Referral Hospital and Medical College, Ethiopia. J AIDS Clin Res. 2014;5(3):289. doi: 10.4172/21556113.1000289

4. Rose AM, Hall CS, Martinez-Alier N. Aetiology and management of malnutrition in HIV-positive children. Arch Dis Child. 2014;99(6):546-51. doi: 10.1136/ archdischild-2012-303348

5. Cotton MF, Violari A, Otwombe K, Panchia R, Dobbels E, van Rensburg AJ, et al. Early limited antiretroviral therapy is superior to deferred therapy in HIV-infected South African infants: results from the children with HIV early antiretroviral (CHER) randomized trial. Lancet. 2013;382(9904):1555-63. doi: 10.1016/S01406736(13)61409-9

6. World Health Organization (WHO). Child growth standards WHO. [series online] 2006 [cited 2020 Desember 11]. Available from: URL: https://www.who.int/toolkits/ child-growth-standards

7. World Health Organization (WHO). Growth reference data for 5-19 years. [series online] 2007 [cited 2020 Desember 11]. Available from: URL: https://www.who.int/toolkits/ growth-reference-data-for-5to19-years

8. Pillay K. Lymph node pathology in the HIV-positive child. Diagnostic Histopathology. 2009;15(5):241-50. doi: 10.1016/j.mpdhp.2009.02.008

9. Mayoclinic. Oral thrush. [series online] 2018 [cited 2020 Desember 10]. Available from: URL: https://www. mayoclinic.org/diseases-conditions/oral-thrush/symptomscauses/syc-20353533

10. Centers for Disease Control and Prevention (CDC). Chronic diarrhea. [series online] 2016 [cited 2020 Desember 10]. Available from: URL: https://www.cdc. gov/healthywater/hygiene/disease/chronic_diarrhea.html

11. World Health Organization (WHO). Pneumonia. [series online] 2019 [cited 2020 Desember 10]. Available from:
URL: https://www.who.int/news-room/fact-sheets/detail/ pneumonia

12. World Health Organization (WHO). HIV. [series online] 2019 [cited 2020 Desember 10]. Available from: URL: https://www.who.int/teams/global-hiv-programme/hivprevention/mother-to-child-transmission-of-hiv

13. Adedemy JD, Agbeille MF, Agossou J, Noudamadjo A, Kpanidja G, et al. Five years sur-vival trend and outcome among HIV infected children followed up in the pediatric department in a tertiary hospital. Int J Pediatr Res. 2019;5:052. doi: 10.23937/2469-5769/1510052

14. Thorne C, Newell ML. Prevention of mother-to-child transmission of HIV infection. Curr Opin Infect Dis. 2004;17(3):247-52. doi: 10.1097/00001432-20040600000013

15. Mutanga JN, Mutembo S, Ezeamama AE, Song X, Fubisha $\mathrm{RC}$, Whalen CC, et al. Long-term survival outcomes of HIV infected children receiving antiretroviral therapy: an observational study from Zambia (2003-2015). BMC Public health. 2019;19:115. doi: 10.1186/s12889-019-6444-7

16. Zanoni BC, Phungula T, Zanoni HM, France H, Feeney ME. Risk factors associated with increased mortality among HIV infected children initiating antiretroviral therapy (ART) in South Africa. PloS one. 2011;6(7):e22706. doi: 10.1371/journal.pone.0022706

17. Collins IJ, Jourdain G, Hansudewechakul R, Kanjanavanit $\mathrm{S}$, Hongsiriwon S, Le Coeur S, et al. Long-term survival of HIV-infected children receiving antiretroviral therapy in Thailand: a 5-year observational cohort study. Clin Infect Dis. 2010;51(12):1449-57. doi: 10.1086/657401

18. Zar HJ, Hanslo D, Tannenbaum E, Klein M, Argent A, Bateman ED, et al. Aetiology and outcome of pneumonia in human immunodeficiency virus $\square$ infected children hospitalized in South Africa. Acta Paediatr. 2001;90(2):119-25.

19. Akintan PE, Adebola A, Edamisan T, Esezobor C. Prevalence of wasting, stunting, and underweight among HIV infected underfives', in Lagos using WHO z score. Nigerian Quarterly Journal of Hospital Medicine. 2015;25(2):124-8.

20. World Health Organization (WHO). Malnutrition. [series online] 2020 [cited 2020 Desember 14]. Available from: URL: https://www.who.int/health-topics/ malnutrition\#tab=tab_1

21. Sashindran VK, Thakur R. Malnutrition in HIV/AIDS: aetiopathogenesis. In: Nutrition and HIV/AIDS-Implication for Treatment, Prevention and Cure. [series online] 2020 [cited 2020 Desember 14]. Available from: URL: https:// ideas.repec.org/h/ito/pchaps/178250.html

22. Dikman AE, Schonfeld E, Srisarajivakul NC, Poles MA. Human immunodeficiency virus-associated diarrhea: still 
an issue in the era of antiretroviral therapy. Dig Dis Sci. 2015;60(8):2236-45. doi: 10.1007/s10620-015-3615-y

23. Duggal S, Chugh TD, Duggal AK. HIV and malnutrition: effects on immune system. Clin Dev Immunol. 2012;2012:784740. doi: 10.1155/2012/784740

24. Huang Z, Liu Y, Qi G, Brand D, Zheng SG. Role of vitamin A in the immune system. J Clin Med. 2018;7(9):258. doi: $10.3390 / \mathrm{jcm} 7090258$

25. Lewis ED, Meydani SN, Wu D. Regulatory role of vitamin $\mathrm{E}$ in the immune system and inflammation. IUBMB life. 2019;71(4):487-94. doi: 10.1002/iub.1976

26. Evalina R. Studi deskriptif infeksi HIV pada anak di Rumah Sakit Umum Pusat Adam Malik Medan. Sari Pediatri. 2012;14(2):73-8. doi: 10.14238/sp14.2.2012.73-8

27. Head BM, Mao R, Keynan Y, Rueda ZV. Inflammatory mediators and lung abnormalities in HIV: a systematic review. PloS one. 2019;14(12):e0226347. doi: 10.1371/ journal.pone. 0226347

28. Iriart X, Witkowski B, Cassaing S, Abbes S, Menard S, Huynh A, et al. Alveolar and blood T lymphocyte profiles in Pneumocystis jirovecii-positive patients: effects of HIV status. J Infect Dis. 2011;204(4):544-53. doi: 10.1093/ infdis/jir302

29. Jambo KC, Sepako E, Fullerton DG, Mzinza D, Glennie S, Gordon SB, et al. Bronchoalveolar CD4+ T cell responses to respiratory antigens are impaired in HIV-infected adults. Thorax. 2011;66(5):375-82. doi: 10.1136/thx.2010.153825

30. Bachou H, Tylleskär T, Downing R, Tumwine JK. Severe malnutrition with and without HIV-1 infection in hospitalised children in Kampala, Uganda: differences in clinical features, haematological findings and CD4+ cell counts. Nutr J. 2006;5:27. doi: 10.1186/1475-2891-5-27 